\title{
Duygusal Uyarılmışlığın Tanıma Belleği Üzerindeki Ketleyici Etkisi: Nesne içi ve Nesneler arası Bağlantıların Karșılaștırıılması
}

\section{Interference Effects of Emotional Arousal on Recognition Memory: Comparison of Within-object and Between-object Bindings}

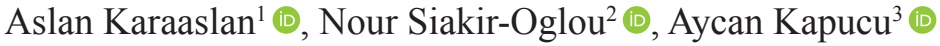

${ }^{1}$ Arş. Gör., Ege Üniversitesi, Edebiyat Fakültesi, Psikoloji Bölümü, İzmir, Türkiye ${ }^{2}$ Technical University of Munich, Arcisstraße 21, TUM Schoolof Education, Marsstraße 20-22, 80335 München, Almanya ${ }^{3}$ Dr. Öğr. Üyesi, Ege Üniversitesi, Edebiyat Fakültesi, Psikoloji Bölümü, İzmir, Türkiye

ORCID: A.K. 0000-0003-3325-4122; N.S.O. 0000-0002-8931-4166; A.K. $0000-0001-7340-9876$

\section{Sorumlu yazar/Corresponding author:} Aslan Karaaslan,

Ege Üniversitesi, Edebiyat Fakültesi Psikoloji Bölümü, Erzene Mahallesi, Bornova,

İzmir, Türkiye

E-posta/E-mail: aslankaraaslan@gmail.com

Başvuru/Submitted: 04.03.2019 Revizyon Talebi/Revision Requested: 04.03.2019

Son Revizyon/Last Revision Received:

12.07.2019

Kabul/Accepted: 19.07 .2019

Online Yayın/Published Online: 06.12.2019

Atıf/Citation: Karaaslan, A., Siakir-Oglou, N., Kapucu, A. (2019). Duygusal uyarılmışlığın tanıma belleği üzerindeki ketleyici etkisi: Nesne içi ve nesneler arası bağlantıların karşılaştırılması. Psikoloji Çalışmaları - Studies in Psychology, 39(2): 293-320. https://doi.org/10.26650/SP2019-0020
ÖZ

Nesne Temelli İlişkilendirme Kuramı'na göre, duygusal uyarılmışlık bir uyaranın içsel özelliğiyle olan bağlantısının hatırlanmasını kolaylaştırırken, dışsal özelliğiyle olan bağlantısının hatırlanmasını zayıflattığını ya da bu bağlantının hatırlanmasına bir etkisi olmadığını öne sürmektedir. Bu çalışma, nesne içi ve nesneler arası bağlantıların bellekte güncellenmesinde negatif duygusal uyarılmışlığın etkilerini araştırmayı amaçlamıştır. Negatif duygusal uyarılmışlık içerikli içsel (nesne içi) eşleşmelerin dışsal (nesneler arası) eşleşmelere göre daha yüksek düzeyde ileriye ket vurmaya neden olması beklenmiştir. Duygu koşulları için seçilen öfkeli, üzgün ve nötr yüz ifadeleri, nötr nesneler olarak çeşitli şapkalar ile eşleştirilmiştir. Nesne içi koşulda şapka, yüz ifadesinin üzerinde bitişik şekilde nesnenin içsel bir özelliği olarak sunulmuşken, nesneler arası koşulda yüz ifadesinin yanında ayrık dışsal bir özellik olarak sunulmuştur. Katılımcılar ilk önce bir dizi yüz-şapka eşleşmelerini öğrenmişler, ardından daha önce gördükleri yüzler ile yeni şapka eşleşmelerini öğrenmişlerdir. Test aşamasında katılımcılar, yarısı doğru yarısı yanlış eşleştirilerek sunulan ikinci listedeki eşleşmelerin doğru mu, yanlış mı olduğuna karar vermişlerdir. Elde edilen veriler Sinyal Tespit Kuramı temelinde incelenmiştir. Sonuçlar nesne içi koşuldaki öfkeli yüzşapka eşleşmelerinin yanlış alarm (YA) oranının, nesneler arası koşuldaki öfkeli yüz-şapka eşleşmelerinin YA oranına göre daha yüksek olduğunu göstermiştir. Yüksek YA oranı, negatif duygusal uyarılmışlık koşulunda nesne içi eşleşmelerin güncellenmesinin zorlaştığına işaret etmektedir. Bellek duyarlılığı (d') analizi sonuçlarına göre her bir duygu açısından nesneler arası eşleşme koşulundaki katılımcılar, nesne içi eşleşme koşulundaki katılımcılara göre doğru ve yanlış eşleşmeleri birbirlerinden daha iyi ayırt edebilmişlerdir. Hem YA hem duyarlılık sonuçları birlikte ele alındığında, araştırma hipotezlerinin desteklendiği, nesne içi eşleşme koşulunda yüksek uyarılmışlığın ileriye ket vurmaya yol açtığı ve böylece belleğin güncellenmesini zorlaştırdığı görülmektedir. Bu sonuçlar Nesne Temelli İlişkilendirme Kuramı'nın, duygusal uyarılmışlığın nesne içi bilginin hatırlanmasında güçlendirici etki ortaya çıkarttığı açıklamasını desteklemektedir. Anahtar Kelimeler: Belleğin güncellenmesi, ileriye ket vurma, bağlantısal bellek, duygusal bellek, negatif duygusal uyarılmışlık 


\section{ABSTRACT}

According to the Object-based Binding Theory, emotional arousal enhances within-object binding, but impairs or does not affect between-object memory binding. The present study aimed to investigate the effects of negative emotional arousal on memory updating of within-object and between-object associations. Negative emotional arousal was expected to cause a higher level of interference in intrinsic associations (within object condition) than in extrinsic associations (between object condition). Angry, sad and neutral facial expressions chosen for emotion conditions are paired with various hats as neutral objects. In the within-object condition, the hat was presented together with a face, while in the between-object condition, the hat was presented as a separate object distinct from the face. First, all participants learned a list of face-hat pairs, then learned a second list with the same faces paired with new hats. In the test phase, the second list of pairs was rearranged into half correct and half incorrect, and the participants decided whether the pairs were correct or incorrect. The data were analyzed on the basis of Signal Detection Theory. We found that higher false alarms were given to angry faces in the within-object condition than in the between-object condition. This high false alarm rate indicates that negative emotional arousal prevented memory updating of within-object associations. According to analysis of memory sensitivity, in all emotion conditions, correct and incorrect pairs were better discriminated in the between-object condition than in the within-object condition. When false alarm rates and sensitivity results are considered together, the hypotheses of the study are supported and it is seen that negative emotional arousal leads to proactive interference in the within-object condition and thus makes it difficult to update memory. These results are consistent with the OBT in that negative emotional arousal exerts an enhancing effect on remembering intrinsic features of objects.

Keywords: Memory updating, proactive interference, associative memory, emotional memory, negative emotional arousal

\section{EXTENDED ABSTRACT}

A growing body of literature has demonstrated that emotionally arousing items are better remembered than non-arousing neutral items (e.g., Cahill \& McGaugh, 1995). However, it is questionable whether the effect of emotional arousal on item memory also extends to associative memory.

According to Object-based Binding Theory (OBT; Mather, 2007) the effects of arousal on memory binding depend on "whether the elements to be bound are part of the same object as the arousing item or whether the binding has to occur between different objects" (Mather, 2007, p.12). The theory asserts that emotional arousal enhances binding when the items are within the arousing objects (within-object binding). On the other hand, emotional arousal either has no effect on binding, or even impairs it, when the item to be bound is outside the arousing item (between-object binding).

Besides learning associations, whether between-object or within-object, it is also essential to keep information in memory updated. Novak and Mather (2009) found that arousal impaired memory updating for within-object associations. Another study testing between-object binding showed that arousal enhanced memory updating (Mather \& Knight, 2008). The present study, therefore, aims to directly compare the effects of negative arousal 
on memory updating for between-object and within-object associations. We predicted that high arousing stimuli would either impair updating or have no effect on it for within-object associations, but instead would facilitate updating for between-object associations.

\section{Method}

Seventy-three undergraduate sociology and psychology students (63 women, 10 men) with an average age of 21.7 years, participated in the experiment. The participants were randomly assigned to one of the experimental conditions: between-object and withinobject conditions. In both conditions, photographs of different types of hats were paired with angry (high arousal and negative), sad (low arousal and negative) or neutral female and male faces. Participants in the between-object condition saw the faces and hats on opposite sides of the screen, whereas participants in the within-object condition saw people (faces) wearing the hats.

Participants were instructed that they were about to view a series of face-hat pairings and that they should study each pair for a subsequent memory test. At the first learning stage, participants were presented pairs in three emotional categories. At the second learning stage, the same faces were matched with new hats and the participants performed a similar task as in the first stage. In the test phase, half of the pairs of the second learning list were matched correctly, half were matched incorrectly, and participants were asked to decide which pair was correct or incorrect. In addition, a five-minute filler task was used between the learning and test phase.

\section{Results}

Following the analysis of variance for interaction, planned comparisons based on hypotheses were conducted for accuracy, false alarm, sensitivity, and bias measures. ${ }^{1}$ False alarms were higher for the angry faces paired with hats in the within-object condition than in the between-object condition, $F(1,71)=5.26, p<.05, \eta_{p}^{2}=.07$. Furthermore, sensitivity results revealed that participants were better able to discriminate between correct and incorrect angry face-hat pairs in the between-object condition than in the within-object condition, $F(1,71)=5.49, p<.05, \eta_{p}^{2}=.07$. Similarly, sadness pairs in the between-object conditions were better able to be discriminated than in the within object conditions, $F(1$, $71)=7.69, \mathrm{p}<.01, \eta_{\mathrm{p}}^{2}=.10$. And, neutral pairs in the between-object conditions were better

1 Because there were some comparisons that did not serve hypotheses (such as the comparison of anger in between objects condition with sadness in within object condition), instead of post-hoc analysis followed by interaction effect, planned comparisons were made with conditions appropriate to the purpose of the study. 
able to be discriminated than in the within object conditions, $F(1,71)=4.93, p<.05, \eta_{\mathrm{p}}{ }^{2}=$ .07. In addition, participants showed a more conservative response bias (were more likely to respond with the word "incorrect") towards sad face-hat pairs compared to angry face-hat pairs in the within-object condition $(p<.05)$.

\section{Discussion}

This study investigated the effects of negative high and low emotional arousal on the updating of memory for between-object and within-object associations via a proactive interference paradigm. As predicted, participants gave more false alarms to high arousing stimuli (hats paired with angry faces) in the within-object condition than in the betweenobject condition. At the same time, in terms of each emotion category, participants were better able to discriminate between correct and incorrect pairs in the between-object condition than in the within-object condition. These findings are consistent with OBT's prediction (Mather, 2007) that remembering the internal properties of an object is more affected by emotional arousal. In addition, it has been shown that emotional arousal leads to memory impairment caused by proactive interference. Unexpectedly, there were no significant differences among emotion categories in the within-object or between-object conditions. 
Bir olayın ya da nesnenin hatırlanmasını etkileyen en önemli faktörlerden birisi sahip olduğu duygusal içeriktir. Duygusal içerik bazı koşullarda daha iyi kodlamaya ve geri getirmeye yol açarken, bazı durumlarda olayın hatırlanmasına yönelik bozucu/ketleyici etkide bulunabilir (Kensinger ve Schacter, 2008; Tyng, Amin, Saad ve Malik, 2017). Duygunun bellek üzerindeki etkisine yönelik çok sayıda çalışma bulunmasına karşın, farklı bellek yapılarında ve nesneler arası ilişkilerde duygunun ne yönde etki yarattığı tartışmalıdır. Bu çalışmada tanıma belleğinde, nesnenin içsel bir özelliğinin hatırlanması ile nesneye eşlik eden bağlantısal bir özelliğin hatırlanması üzerinde duygusal uyarılmışlığın etkisi araştırılmıştır. $\mathrm{Bu}$ amaçla iki temel soruya yanıt aranmıştır. Bunlardan ilki, belleğin güncellenmesinde (memory updating), başka bir deyişle ileriye dönük ket vurmada (proactive interference) duygusal uyarılmışlığın etkisinin var olup olmadığı sorusudur. İkincisi, duygusal bir nesnenin içsel bir özelliğinin hatırlanması ile duygusal nesneye eşlik eden dışsal bir bilginin hatırlanmasının ileriye ket vurma açısından farklılaşıp farklılaşmadı̆̆ı sorusudur.

Alan yazın incelendiğinde duygu ve belleğe ilişkin çeşitli yaklaşımlar ve tanımlamalar olduğu görülmektedir. Duygunun tanımına ilişkin genel kabul gören tanımlamalardan birisinde Scherer (2005), duyguyu, organizmayı ilgilendiren dişsal ve içsel uyaranların değerlendirilmesine yönelik beş alt sistemin (biliş, fizyolojik düzenleme, motivasyon, motor dışavurum, içsel durumu izleme) tümünde ya da çoğunda birbiriyle ilişkili, eşzamanlı değişimlerin olduğu zaman dilimi olarak tanımlar. Duygunun işlevine yönelik açıklamalar duygunun diğer bilişsel işlevlerde olduğu gibi organizmanın karşılaştığı yaşamsal problemlere uyum sağlayıcı çözümler üretmeye hizmet eden yapılar olduğuna işaret eder (Tooby ve Cosmides, 2008). Bu anlamda duygu ve diğer bilişsel süreçler (dikkat, bellek, yürütücü işlevler, vb.) arasında doğrudan ve dolaylı bir ilişkinin olduğu düşünülebilir.

Duygu gibi bellek de tekil bir yapıdan oluşmamaktadır. Bir olayı, kişiyi ya da nesneyi hatırlamak çok sayıda bilgiyi bir arada kodlamayı gerektirir. Tekil bir nesneyi hatırlama (nesne belleği) ile nesneler arası ilişkiyi hatırlama (bağlantısal bellek) arasında kodlama ve geri getirmeye yönelik bilişsel süreçler açısından farklılıklar olacaktır (Johnson ve Raye, 2000; Mather, 2007). Örneğin görgü tanı̆̆ı belleğinde 'Soyguncunun elinde ne vardı?' ya da 'Soyguncunun arkasındaki masanın üzerinde ne vardı?' soruları nesne belleğini ölçmektedir. 'Silah hangi soyguncunun elindeydi?' sorusu ise kişinin nesneler arasındaki ilişkileri ne kadar iyi kurduğuyla, dolayısıyla bağlantısal bellek ile ilgilidir. Bununla birlikte, bazen de ilk öğrenmenin sonraki öğrenmeleri nasıl etkilediği incelen- 
miştir. Örneğin, 'Silah en son hangi soyguncunun elindeydi?' sorusu belleğin güncellenmesine işaret eder. Ancak belleğin güncellenmesi her zaman mümkün olmayabilir (Mather, 2007). Örneğin, silahın ilk kimde olduğu bilgisi, sonra kimde olduğu bilgisini öğrenmemizi engelliyorsa belleğin güncellenmesindeki bir sorundan, dolayısıyla ileriye ket vurmanın bir etkisinden söz edilebilir.

Duygunun bellek üzerindeki etkisinden söz ederken, tıpkı bellek yapılanmasında olduğu gibi tek bir duygusal boyuttan bahsetmek mümkün değildir. Alanda kabul görmüş çeşitli duygu kuramları olmakla birlikte yaygın kabul edilen açıklamalardan birisi duygunun iki temel boyutta yapılandığını ortaya koyan döngüsel modeldir (Posner, Russell ve Peterson, 2005; Russell, 1980). Döngüsel modele göre, farklı duygular kişide yol açtığı aktivasyonu ifade eden uyarılmışlık ve uyaranın arzulanırlığını ifade eden değerlik olmak üzere iki boyut üzerinde konumlandırılabilmektedir. Örneğin, öfke yüksek uyarılmışlık ve negatif değerliğe, hoşnutluk ise düşük uyarılmışlık ve pozitif değerliğe sahip duygulardır.

Alan yazın incelendiğinde, duygu ve bellek arasındaki etkileşime yönelik çalışmalarda hem duygunun genel etkisinin hem de duygunun uyarılmışlık ve değerlik boyutları özelindeki etkisinin ele alındığı görülmüştür. Tanıma belleği çalışmalarında çoğunlukla nesne içi bağlantıları içeren uyaranların tanınması ele alınmış ve duygusal içeriğin bellekteki güçlendirici etkisine yönelik bulgular elde edilmiştir. Duygunun tanıma belleğindeki bu türden bir güçlendirici etkisi video (Cahill ve ark., 1996), fotoğraf (Bradley, Greenwald, Petry ve Lang, 1992; Hamann, Ely, Grafton ve Kilts, 1999; Kensinger, Brierley, Medforf, Growdon ve Corkin, 2002), kelime (Kensinger ve ark., 2002, Nagae ve Moscovitch, 2002; White, Kapucu, Bruno, Rotello ve Ratcliff, 2014) gibi çeşitli uyaranlarla yapılan çalışmalarla gösterilmiştir. Ancak bu çalışmalarda uyaranın hangi detaylarının bellekte sağlamlaştığ 1 ve geri getirmede öncelikli hale geldiği, ayrıca duygunun hangi boyutları açısından bu etkinin gözlendiği soruları hala yanıtlanmaya gereksinim duymaktadır. Duygunun bellek performansı üzerindeki güçlendirici etkisine yönelik açıklamalardan birisi Easterbrook'un (1959) 'bellek daralması hipotezi'dir. Buna göre, duygu, dikkati merkezi bilgilere yoğunlaştırarak bu bilgilerin daha iyi kodlanmasına yol açmaktadır. Ancak merkezi bilgiye odaklanan dikkat, çevresel bilgilerin detaylı işlenmesinin önüne geçerek hatırlanma olasılığını düşürmektedir. Banka soygunu örneğinde, silahlı kişi merkezi detay, onun uzağında bulunan masanın üzerindeki nesneler ise çevresel detay olarak değerlendirilirse, bu hipoteze göre silahlı kişi ve ona dair detaylar iyi hatırlanacakken, masanın üzerindeki nesnelerin hatırlanma olasılığı daha düşük olacaktır. Öte taraftan, 
herhangi bir duygu içermeyen bir sahnede dikkat bütün sahneye eşit bir şekilde dağılacaktır, dolayısıyla merkezi ve çevresel bilgilerin kodlanma ve hatırlanma olasılığı eşit olacaktır (Easterbrook, 1959). Bu çalışmalar, duygunun çevresel ve merkezi bilgilerin hatırlanmasında (nesne belleği) farklı etkileri olduğuna işaret etmekle birlikte, bir nesneye eşlik eden diğer nesnenin hatırlanmasına (bağlantısal bellek) dair bir bilgi vermemektedir. Dolayısıyla bellek daralması hipotezinin duygusal nesneyle bir arada bulunan diğer nesnelerin hatırlanması üzerinde, duygunun güçlendirici ya da zayıflatıcı etkisine yönelik açıklama sunmakta yetersiz olduğu düşünülmektedir.

Bellek daralması hipotezinden farklı olarak Uyarılmışlığa Dayalı Rekabet Kuramı (Arousal-biased Competition Theory; Mather ve Sutherland, 2011), hem nesne belleği hem de bağlantısal bellek ile ilgili öngörülerde bulunmaktadır. Buna göre, sınırlı kapasitesi olan dikkatimizi pek çok bilgi arasından önceliği olan bilgilere yöneltiriz. Bir bilginin önceliği iki şekilde belirlenebilir. Birincisi, uyaran zıtlık, parlaklık, hareketlilik gibi algısal özelliklerinden dolayı diğerlerinden ayrılıyorsa aşağıdan yukarıya işlemeyle dikkati üzerine çeker. İkinci olarak, o uyaran kişinin amacına veya beklentilerine uygun olduğu durumlarda yukarıdan aşağıya işleme ile algıda öncelik kazanır (Mather ve Sutherland, 2011). Duygunun hem aşağıdan yukarıya (Knight ve ark., 2007; LaBar, Mesulam, Gitelman ve Weintraub, 2000; Nummenmaa, Hyona ve Calvo, 2006; Rösler ve ark., 2005), hem de yukarıdan aşağıya süreçlerde güçlendirici etkisinin olduğu gösterilmiştir (Lee ve ark., 2010). Uyarılmışlığa Dayalı Rekabet Kuramı, uyaranın duygusal uyarılmışlık düzeyinin öncelikli hatırlamada belirleyici olduğunu öne sürer. Eğer iki nesne arasındaki ilişkinin hatırlanması gerekiyorsa, yüksek uyarılmışlıkla eşleşen nesne, düşük uyarılmışlıkla eşleşen nesneye kıyasla daha iyi hatırlanacaktır (Mather ve Sutherland, 2011). Guillet ve Arndt (2009), Uyarılmışlığa Dayalı Rekabet Kuramı'nın bağlantısal bellek ile ilgili öngörülerini destekleyen bulgular elde etmiştir. Sunulan kelime çiftlerindeki iki kelimeden birinin yüksek uyarılmışlıkta olduğu durumda, her iki kelimenin de nötr olduğu duruma göre kelime çiftinin daha iyi hatırlandığı yani bağlantısal bellek performansının daha yüksek olduğu bulunmuştur.

Mather'in (2007) Nesne Temelli İlişkilendirme Kuramı, bellek daralması hipotezi ve Uyarılmışlığa Dayalı Rekabet Kuramı’nın göz ardı ettiği önemli bir noktaya değinmektedir. Bu kurama göre, duygusal uyarılmışlığın bağlantısal bellek üzerindeki etkisi bağlantının türüne göre değişmektedir. Duygusal uyarılmışlığın yüksek olduğu nesnenin içsel özellikleri birbirleriyle ilişkilendirilerek daha yüksek hatırlamaya neden olmakta- 
dır. Ancak duygusal uyarılmışlık ifade eden bir nesne, kendisine eşlik eden diğer dışsal nesnelerin ve bağlamsal bilgilerin hatırlanmasında bir artışa neden olmayacaktır. Ya da bu bilgilerin hatırlanma olasılığını düşürecektir. Bunun nedeni bağlantısal nesnenin daha az dikkat çekmesi ve bu yüzden iki nesne arasında sağlam bir bağın oluşturulmasının engellenmesidir (Mather, 2007). Duygusal uyarılmışlığın bir nesnenin içsel özellikleriyle eşleştirilmesinde güçlendirici rolünün olduğunu gösteren çok sayıda araştırma bulunmaktadır. Örneğin, Doerksen ve Shimamura (2001), katılımcıların duygusal kelimelerin rengini (nesne içi özellik) nötr kelimelerin rengine göre daha iyi hatırladıklarını göstermiştir. Farklı görevlerin kullanıldığı çeşitli araştırmalarda da benzer bulgular elde edilmiştir (D’Argembeau ve Van der Linden, 2004; Kensinger ve Corkin, 2003; MacKay ve ark., 2004). Bir nesnenin rengi gibi, bir alandaki konumu da o nesnenin içsel bir özelliği olarak değerlendirilmektedir. Duygusal uyarılmışlığın kelime (D’Argembeau ve Van der Linden, 2004) ve fotoğraf (Mather ve Nesmith, 2008) uyaranlarının konumlar1nın hatırlanmasında olumlu etki yarattığı bilinmektedir. Nesne Temelli İlişkilendirme Kuramı aynı zamanda uyarılmışlığın, uyaranın uzamsal alanı dışında bulunan bir nesneyle eşleştirilmesini zorlaştırdığını ya da bu eşleştirme üzerinde herhangi bir etki yaratmadığını öne sürmektedir (Mather, 2007). Ancak nesneler arası süreçlere ilişkin bu türden bir öngörünün test edildiği çok az sayıda çalışma vardır ve bu açıklamanın yeni çalışmalarla desteklenmesi gerekmektedir. Her ne kadar Nesne Temelli İlişkilendirme Kuramı uyarılmışlığın iki farklı nesneler arası süreçteki etkisini açıklayan kapsamlı bir kuram gibi görünse de, alanda bu kuramın açıklamalarıyla örtüşmeyen bazı bulgular da mevcuttur. Örneğin, Guillet ve Arndt'ın (2009) yürüttüğü kelime çiftlerini hatırlama deneyinde, kelimelerden birinin duygusal olmasının hatırlama performansını artırdığı bulgusu bu kuramla çelişmektedir. Duygusal bir kelime ile eşleşen nötr kelimeler dişsal eşleşmeler olarak değerlendirilirse, Nesne Temelli İlişkilendirme Kuramı'na göre duygunun bellek performansını düşürücü bir etkisinin ortaya çıkması beklenirdi.

Duygusal uyarılmışlığın bellek üzerindeki bozucu etkisinin bir nedeninin ileriye ket vurma olduğunu gösteren çalışmalar mevcuttur. Örneğin, duygu içerikli uyaranlar arasındaki bağlantıların nötr bağlantılara göre daha fazla ileriye ket vurmaya neden olduğu görülmüştür (Mitchell, Mather, Johnson, Raye ve Greene, 2006). Novak ve Mather (2009) bu olguyu test etmek üzere katılımcılara ekranın sekiz farklı yerinde görüntülenen duygusal içerikli (uyarılmışlık düzeyi yüksek) ve nötr fotoğraflar sunmuştur. Katılımcılardan bu fotoğrafları ekrandaki konumları ile birlikte hatırlamaları istenmiştir. 
Test aşamasında katılımcılardan daha önce gördükleri bu fotoğrafların ekranın hangi alanında sunulduğunu belirtmeleri istenmiştir. Katılımcıların testte hata yapmaları durumunda, bu öğrenme ve test bloğu tüm fotoğrafların konumları iki kez doğru şekilde hatırlanana kadar tekrarlanmıştır. Sonuç olarak, katılımcıların ilk testteki hatırlama performansları duygusal ve nötr fotoğraflar arasında farklılaşma göstermemiştir. Ancak iki öğrenme aşamasındaki yanlış tanıma oranları incelendiğinde, katılımcılar duygusal fotoğraflarda yaptıkları yanlışları nötr fotoğraflarda yaptıkları yanlışlara göre daha fazla tekrarlamışlardır. Dolayısıyla ilk öğrenmede yanlış bir bağlantı kurulduğunda sonraki aşamalarda doğrusunu öğrenmek, duygusal fotoğraflar için nötr fotoğraflara kıyasla daha zor olmuştur. Araştırmacılar bu sonucun ileriye ket vurmadan kaynaklandığından emin olabilmek için bir öğrenme ve test bloğu daha uygulamış, ancak bu kez fotoğrafların yarısının konumlarını değiştirmişlerdir. Katılımcılar duygusal fotoğrafların yeni konumlarını öğrenmekte yine daha başarısız olmuşlardır. Araştırmacılar bu bulgulardan bağlantısal bellekteki duygu içerikli anıların nötr anılara göre değiştirilmesinin ve güncellenmesinin daha zor olduğu çıkarımını yapmışlardır (Novak ve Mather, 2009). Ancak bu araştırmanın bulguları uyaranın içsel özelliğiyle (fotoğrafın konumuyla) ilişkilidir ve nesneler arası süreçler hakkında bilgi vermemektedir. İki ayrı uyaranın ilişkilendirilmesini (nesneler arası bağlantıyı) ele alan ileriye ket vurma çalışmalarının bir kısmı uyarılmışlığın ileriye ket vurmayı artırdığını gösterirken (örn., Bisby ve Burgess, 2014; Mather ve Knight, 2008), bir kısmı da uyarılmışlığın bağlantısal bellek performansına bir etkisi olmadığını göstermiştir (örn., Sakaki, Ycaza-Herrera ve Mather, 2014). Sonuç olarak, mevcut alan yazın içsel-dışsal bağlantıların öğrenilmesinde uyarılmışlığın ileriye ket vurmaya neden olup olmadığı konusunda tartışmalıdır. Bu çalışmanın bir amacı duygusal uyarılmışlığın nesne belleği ile bağlantısal bellek arasındaki etkisinin farklılaşıp farklılaşmadığını ileriye ket vurma süreçleri açısından ele almaktır. Öte yandan, alandaki çalışmalar duygunun bağlantısal bellek performansına etkisinde çoğunlukla uyarılmışlık düzeyinin rolüne vurgu yapsa da (Bkz. Bradley ve ark., 1992; Mather, 2007; Mather ve Sutherland, 2009), McKenzie, Powell ve Donaldson (2015) yaptıklar1 çalışmada Nesne Temelli İlişkilendirme Kuramı ile tutarsız bir sonuç olarak, hem nesne içi hem nesneler arası eşleşmelerde uyarılmışlıktan ziyade negatif değerliğin belleği zayıflatıcı etkisi olduğunu göstermiştir. Pierce ve Kensinger (2011) ise sadece negatif değerlik boyutundan ya da sadece uyarılmışlıktan değil, bu iki boyutun etkileşiminden ortaya çıkan bir etkiden söz etmektedir. Kapucu, Arıkan İyilikçi, Eroğlu ve Amado (2018), duygunun uyarılmışlık ve değerlik boyutlarının yanında motivasyonel boyutun da bel- 
lekte kodlama ve geri getirme süreçleri üzerinde etkili olduğunu göstermiştir. Bununla birlikte, Kaynak ve Gökçay (2017) duygunun değerlik boyutunun, yaşlılarda doğru tanıma performansı üzerindeki etkisinin pozitif duygusal uyaranlara karşı bir tepki yanlılığı oluşturduğunu göstermiştir. Ket vurma araştırmalarına bakıldığında yine uyarılmışlığın ve negatif değerliğin birlikte ket vurmayı artırdı̆̆ı görülmektedir (Novak ve Mather, 2009). Novak ve Mather (2009), gelecekteki araştırmalarda duygusal uyaranın tam olarak hangi özelliklerinin (uyarılmışlık, değerlik boyutu ya da başka faktörler) ket vurmayı artırdığını belirlemenin önemine işaret etmektedir. Dolayısıyla alandaki bir diğer tartışmalı konu, uyarılmışıı̆ğn ileriye ket vurmada tek başına bir etkisinin olup olmadığıdır. Bu tartışmalı açıklamalara bağlı olarak bu çalışmanın bir amacı da aynı değerliğe sahip (negatif) yüksek ve düşük uyarılmışlık düzeyleri arasında, ileriye ket vurma açısından bir farklılık olup olmadı̆̆ını test etmektir.

Alan yazındaki mevcut eksikliklerden yola çıkarak bu çalışma, negatif duygusal uyarılmışlığın tanıma belleğinde ileriye ket vurmaya neden olup olmadığını ve bu olası etkinin nesne içi ve nesneler arası süreçlerde farklılaşıp farklılaşmadığını test etmek üzere yürütülmüştür. Alanda nesne belleği üzerinde duygusal uyarılmışlığın etkisi çok sayıda çalışmada test edilmiş olsa da, nesneler arası süreçlere ilişkin çalışmalar yetersizdir ve az sayıdaki mevcut çalışma da çelişkili bulgular ortaya koymuştur. Bu çalışma, ileriye ket vurma paradigması kullanılarak nesne belleğinde ile bağlantısal bellekte uyarılmışlığın belleğin güncellenmesi üzerindeki etkisini incelemeyi amaçlamaktadır. Aynı zamanda alan yazında tanıma belleği performansı ölçümü için sıklıkla doğruluk puanlar1 ve isabet oranları kullanılmaktadır. Ancak, literatürde tanıma belleğinde daha güvenilir bir ölçüm olarak doğru eşleşmelerin yanlış eşleşmelerden ayırt edilebilme becerisini ifade eden duyarlılık parametresinin kullanılması önerilmektedir (Macmillan ve Creelman, 2005). Bu çalışmada sinyal tespit teorisi temelinde duyarlılık analizi de gerçekleştirilerek tanıma performansına ilişkin daha güvenilir bir ölçüm alınması amaçlanmıştır.

$\mathrm{Bu}$ çalışmada, belleğin güncellenmesinin negatif duygusal uyarılmışlık boyutundan ne kadar etkilendiği ve bunun bağlantının türüne (nesne içi ya da nesneler arası bağlantı) göre değişip değişmediği ele alınmaktadır. Duygusal uyarılmışlık belleğin güncellenmesini engelliyorsa (Mather, 2007), duygusal uyarılmışlığı yüksek nesne, içsel ya da dışsal bir özellikle bir kez eşleştikten sonra, aynı duygusal uyaranın sonraki başka bir özellikle eşleşmesinin öğrenilmesini ve dolayısıyla hatırlanmasını (ileriye ket vurmadan dolayı) zorlaştıracağı öngörülebilir. Ancak, farklı bellek türleri arasında kodlama ve geri getirme 
süreçleri açısından farklılık olduğu bilindiğine göre (Johnson ve Raye, 2000; Mather, 2007), duygusal uyarılmışlığın nesne belleği ve bağlantısal bellek üzerinde de bellek bozulması açısından farklı etkiler ortaya çıkartacağı öngörülebilir. Buna göre, Nesne Temelli İlişkilendirme Kuramı'nın öne sürdüğü biçimde uyarılmışlık, nesne içi bilginin hatırlanmasını zorlaştıracakken ilişkili nesnenin hatırlanmasında (nesneler arası ilişkilerde) bir etkide bulunmayacaktır. Bu öngörülerden hareketle, bu çalışmada ileriye ket vurma paradigmasıyla iki öğrenme aşamasında duygusal uyaranlarla eşleşen nötr uyaranların tanıma belleği performansı karşılaştırılmıştır. Araştırma sonucunda, negatif yüksek uyarılmışlık ifade eden bir uyaran nötr bir uyaranla eşleştiğinde, aynı duygusal uyaranın sonraki yeni bir nötr uyaranla eşleşmesi durumunda, bu ikinci öğrenmeye ilişkin belleğin güncellenmesinin daha zor olması ve dolayısıyla tanıma belleği performansının düşmesi beklenmektedir. Ancak bu türden bir bozulmanın nesne içi uyaran eşleşmelerinde ortaya çıkması beklenirken, nesneler arası eşleşmelerde benzer bir ileriye ket vurma etkisinin ortaya çıkması beklenmemektedir. Buna göre çalışmanın hipotezleri şu şekildedir.

Hipotez 1: Nesne içi koşulda, negatif yüksek uyarılmışlık düzeyindeki yüz ifadesi eşleşmelerinde, düşük uyarılmışlık düzeyindeki eşleşmelere göre daha yüksek tanıma performansı ortaya çıkacaktır.

Hipotez 2: Nesne içi koşuldaki eşleşmelerin her birisinde (öfke, üzüntü, nötr) nesneler arası koşuldaki aynı duygu eşleşmelerine göre daha yüksek tanıma performansı ortaya çıkacaktır.

\section{YÖNTEM}

\section{Katılımcilar}

Çalışmaya Ege Üniversitesi Edebiyat Fakültesi’nin Sosyoloji ve Psikoloji bölümlerinde okuyan, yaş ortalaması $21.7(S S=1.40)$ olan toplam 73 kişi (63 kadın, 10 erkek) katılmıştır. Bu katılımcılardan 37 kişi nesneler arası koşula, 36 kişi ise nesne içi koşula seçkisiz olarak atanmıştır. Pilot çalışmaya ise yaş ortalaması 21.6 $(S S=1.71)$ olan 38 kişi (29 kadın, 9 erkek) katılmış ve katılımcılar iki koşula seçkisiz olarak atanmıştır. Örneklem göz kusuru olmayan ya da deney esnasında lens/gözlük kullanan kişilerden oluşmaktadır. Bütün katılımcılar araştırmaya katılmaya gönüllülük gösteren kişilerden seçilmiştir. Araştırmanın etik kurul onayı Ege Üniversitesi Bilimsel Araştırmalar ve Yayın Etiği Kurulu'ndan alınmıştır. 


\section{Veri Toplama Araçları}

Araştırmada uyaran olarak öfke, üzüntü ve nötr duygu içeren yüz ifadesi fotoğrafları için FACES (Ebner, Riediger ve Lindenberg, 2010) bataryasında bulunan genç model fotoğrafları kullanılmıştır. 12 kadın ve 12 erkek yüzü olmak üzere 24 modele ait nötr, öfkeli ve üzgün yüz ifadelerini içeren toplam 72 (24 yüz x 3 duygu) fotoğraf seçilmiştir. Tüm fotoğrafların boyutları $(2835 \times 3543$ px $)$ sabit tutularak, gri renkte olan arka zeminleri genişletilmiştir.

Çalışmada Google' da açık kaynak olarak sunulan 24 kadın ve 24 erkek şapka fotoğrafları GIMP 2.8 açık kaynak fotoğraf düzenleme aracı ile işlenerek yüz fotoğraflarına uygun hale getirilip kullanılmıştır. Şapka fotoğraflarının seçiminde karıştırıcı olabileceği düşünülen değişkenleri elemek için fotoğrafların seçiminde, fotoğraf çözünürlüğünün yüksek olması, şapka açısının yüz fotoğrafına uygun olması, kırmızı gibi çarpıcı renkler veya süsler içermemesi, şapkaların birbirine çok fazla benzememesi fakat aynı zamanda bellek performansını artıracak biçimde dikkat çekici olmaması ölçütleri kullanılmıştır. Ayrıca katılımcıların göreve alışması için deneyin başında bir deneme aşaması yürütülmüştür. Deneme aşamasında uyaran olarak, yukarıda sözü geçen şapka ve yüz uyaranlarından farklı iki yüz ifadesi ve iki şapka kullanılmıştır.

\section{İşlem}

Deney Ege Üniversitesi Psikoloji Bölümü laboratuvarında her bir katılımcı için bireysel olarak yürütülmüştür. Laboratuvara alınan katılımcılar bilgilendirilmiş onam formunu imzaladıktan sonra bilgisayar aracılığıyla ve sözel olarak deneysel görev hakkında bilgilendirilmişlerdir. Deneyde uyaranların sunumu ve tepki kaydının alınması OpenSesame 3.1.9 açık kaynak kodlu bilgisayar yazılımı ile gerçekleştirilmiştir.

Çalışmada ileriye ket vurmanın etkileri, bu alanda sıklıkla kullanılan klasik bir AB/ AC paradigması ile incelenmiştir. Buna göre ilk öğrenme aşamasında duygusal bir yüz ifadesi bir şapka ile eşleştirilmiştir. Ardından ikinci öğrenme aşamasında aynı yüz ifadesi başka (yeni) bir şapka ile eşleştirilmiştir. Böylece test aşamasında ikinci eşleşmenin sunulmasıyla, ilk öğrenmenin ikinci öğrenme üzerindeki ileriye ket vurma etkisi incelenmiştir. Deney, deneme aşaması ile birlikte toplam 6 aşamadan oluşmaktadır: birinci öğrenme, ara görev, ikinci öğrenme, ara görev ve test. Deneyde iki nesne ilişkisi koşulu oluşturulmuştur: nesneler arası koşulda yüz ve şapka çiftleri yan yana, nesne içi koşulda ise şapka modelin saçını örtecek şekilde (kişinin şapkayı taktığı görünümünde) sunulmuştur. Katılımcılar seçkisiz olarak bu koşullardan birisine atanmıştır. 
Deneyin başında bir deneme aşamasıyla, katılımcıların deneye aşina olmasını sağlamak ve olası sorularını açıklığa kavuşturmak üzere iki örnek yüz-şapka eşleşmesi sunumu gerçekleştirilmiş ve test aşamasında olacağ gibi iki örnek test sorusu sorulmuştur. Katılımcının görevi anladığından emin olduktan sonra birinci öğrenme aşamasına geçilmiştir. Birinci öğrenme aşamasında her bir denemede katılımcıya ekranda 500 ms. süresince bir sabitleme (fixation) noktası gösterildikten sonra bir yüz-şapka eşleşmesi sunulmuştur. Katılımcının hangi koşulda olduğuna bağlı olarak şapka ya bir içsel nesne (nesne içi koşulu) ya da bir dışsal nesne (nesneler arası koşulu) olarak sunulmuştur. Katılımcının hem yüz ifadesine hem de şapkaya odaklanması ve bu yüz-şapka çiftlerini daha sonraki test aşamasında hatırlamak üzere öğrenmesi gerektiği söylenmiştir. Yüz-şapka uyaranları 3000 ms. boyunca ekranda kaldıktan sonra her bir eşleşmeden sonra ekranın ortasında yeşil veya sarı renkte bir daire sunulmuş ve katılımcılardan dairenin hangi renkte olduğuna klavyedeki iki tuştan birine basarak karar vermeleri istenmiştir. Daire görevinin amacı katılımcıların dikkatlerini az önce gördükleri uyarandan uzaklaştırıp bir sonraki eşleşmeye hazırlamak ve böylece önce görülen eşleşmelerin bir sonraki eşleşmenin performansını etkilemesinin önüne geçmektir. Bu işlem döngüsü tüm 24 yüz-şapka çifti için aynı şekilde tekrarlanmıştır. Katılımcılar dört nötr, dört üzgün ve dört öfkeli kadın yüzü ile eşleştirilmiş farklı kadın şapkaları ve dört nötr, dört üzgün, dört öfkeli erkek yüzü ile eşleştirilmiş farklı erkek şapkalarını üç tekrarla görmüştür. Her katılımcı şapka ve yüzlerin önceden eşleştirilmiş dört farklı eşleşme havuzundan seçkisiz olarak birisinde yer almış ve uyaran çiftleri her bir katılımcıya seçkisiz sırada sunulmuştur. Diğer aşamalara geçmeden önce katılımcı gördüğü yüz-şapka çiftlerini tekrar göreceğine dair bir uyarı almıştır. Arkasından katılımcıya ikinci ve üçüncü bloklarda aynı uyaran çiftleri seçkisiz olarak değişen sırada sunulmuştur. Böylece katılımcıların aynı eşleşmeleri (AB) üç kez görerek yeterli öğrenmeyi gerçekleştirmeleri sağlanmıştır ${ }^{1}$.

1 Asıl deneyden önce katılımcıların yüz - şapka eşleşmelerini belleğe kodladıklarından emin olmak için bir pilot çalışma yürütülmüştür. Pilot çalışmada, katılımcıların uyaran eşleşmelerini üç tekrarda başarılı bir şekilde öğrenip öğrenemedikleri test edilmiştir. Katılımcıların üç tekrar sonunda toplam eşleşmelerin yaklaşık \% 80 'ini doğru olarak tanıması başarılı öğrenme ölçütü olarak kabul edilmiştir. Pilot çalışma, deney aşamasına benzer işlemle gerçekleştirilmiştir; ancak pilot çalışmada asıl deneyden farklı olarak yalnızca birinci öğrenme aşaması (üç tekrarla) sunulmuş ve arkasından beş dakikalık bir ara görev verilmiştir. Daha sonra, ikinci öğrenme ve ikinci ara görev aşamaları yürütülmeden doğrudan test aşamasına geçilmiştir. Sonuçlarda, nesne içi koşulun doğru tanıma oranı \% 79; nesneler arası koşulun doğru tanıma oranı \% 82 olarak bulunmuştur ve koşullar arasında anlamlı bir farklılaşma olmadığı görülmüştür $(p>.05)$. Bu sonuçlarla her iki koşulda da üç tekrarın yeterli öğrenmeyi sağladığı sonucuna ulaşılmış ve asıl deneyde hem birinci hem ikinci öğrenme aşamalarında üç tekrar yapılmasına karar verilmiştir. 
Test aşamasına geçmeden önce katılımcıların zaman geçirmesini sağlamak ve uyaran eşleşmelerine yönelik aktif sağlamlaştırma sürecinden dikkatini uzaklaştırmak için yürütülen ara görevlerde, katılımcı beş dakika boyunca basit matematik problemleri çözmüştür. Illk ara görevin sonunda katılımcı "Lütfen deneyciye haber veriniz" yazısı üzerine deneyciyi çağırmıştır. Deneyci katılımcıya az sonra sunulacak olan listede aynı yüzlerin farklı şapkalarla eşleştirildiğini ve bunları daha sonra yapılacak olan tanıma testi için öğrenmesi gerektiğini söylemiştir. İkinci öğrenme aşamasında da, ilk öğrenme aşamasındaki sunum sürelerine, akış şemasına ve seçkisizleştirme sürecine benzer bir işlem gerçekleştirilmiş ancak katılımcıların ilk öğrenme aşamasında gördükleri yüz ifadeleri yeni şapkalarla eşleştirilmiştir. Uyaranlar yine üç blok halinde sunulmuştur. İkinci öğrenmeden sonra ikinci ara görevde de beş dakika boyunca basit matematik problemleri sunulmuştur. $\mathrm{Bu}$ aşama tamamlandıktan sonra deneyin öğrenme aşaması sona ermiştir. Test aşamasına geçildiğinde katılımcı ikinci öğrenme aşamasında gördüğü eşleşmelerin yarısını doğru eşleşme olarak, diğer yarısını yanlış eşleşme olarak karışık sırada görmüştür. Katılımcı her bir eşleşmeden sonra o eşleşmenin daha önce gördüğü eşleşme (doğru eşleşme) olup olmadığına 1 ("kesinlikle yanlış”) ile 6 ("kesinlikle doğru”) değerleri arasında bir güven değerlendirmesi ölçeği üzerinden karar vermiştir (Bkz. Şekil 1). Deneyin süresi her bir katılımcı için yaklaşık 25 dakikadır.

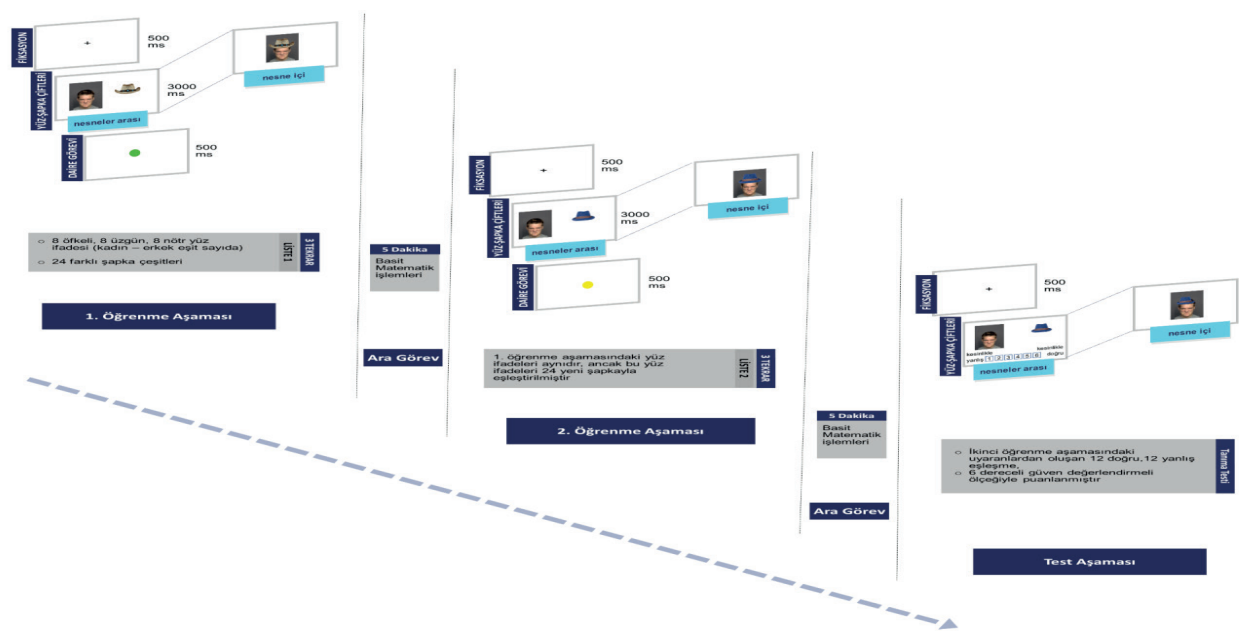

Şekil 1. Deneydeki Uyaran Sunum Sürecini Gösteren Örnek Akış Şeması 


\section{Araştırma Deseni}

$\mathrm{Bu}$ çalışmanın araştırma deseni 3 (duygusal uyarılmışl1k: öfkeli, üzgün ve nötr yüz ifadesi) X 2 (koşul: nesne içi uyaran, nesneler arası uyaran) karışık deney desenidir. Denek içi değişken olan duygusal uyarılmışlığı değişimlemek amacıyla döngüsel modeldeki boyutlar temel alınarak (Russell, 1980; Russell ve Barrett, 1999) negatif değerlikteki yüksek uyarılmışlık düzeyi için öfkeli yüz ifadeleri, düşük uyarılmışlık düzeyi için üzgün yüz ifadeleri ve kontrol koşulu için ise nötr yüz ifadeleri kullanılmıştır. Nesne içi ve nesneler arası süreci karşılaştırabilmek için Mather ve Knight'ın (2008) kullandığı deneysel işleme benzer biçimde duygusal bir yüz ifadesi ile nötr bir nesne olarak şapka eşleştirmeleri kullanılmıştır. Hem öfke hem de üzüntü duyguları negatif değerlikte duygular olduğundan çalışmadan elde edilecek bulguların uyarılmışlık etkisine bağlı olarak ortaya çıkacağı varsayılmıştır. Çalışmada denekler arası değişken olarak, yüz ifadelerinin şapkalarla eşleşme durumu ele alınmıştır. Bu değişkenin düzeyleri şapkanın yüz ifadesine göre bulunduğu konumun türü, nesne içi (yüzün üstünde bir bütün olarak) ve nesneler arası (yanında ayrık bir nesne olarak) eşleşmelerdir (örnek eşleşmeler için bkz. Ek 1).

\section{Veri Analizi}

Deneyde bağımlı değişkenler olarak isabet, yanlış alarm, duyarlılık ( $d$ ') ve tepki yanlılığı $(c)$ puanları hesaplanmıştır. Deneyden elde edilen verilerin analizi IBM SPSS 20 paket programı kullanılarak karışık desenler için varyans analizi ile gerçekleştirilmiştir. Çalışmanın hipotezleri temelinde planlı karşılaştırmalar yürütülmüştür. ${ }^{2}$ Analizlerde yapılan bütün planlı karşılaştırmalar için Bonferroni düzeltmesi uygulanmış ve sonuçlar bu düzeltmeler temelinde raporlanmıştır.

Çalışmanın test aşamasında yüz-şapka eşleşmeleri için güven değerlendirmeleri Sinyal Tespit Kuramı çerçevesinde ROC analizlerinin yapılması amacıyla alınmıştır (Macmillan ve Creelman, 2005). Ancak elde edilen veriler incelendiğinde, 6'lı güven değerlendirmesi ölçeğinde her bir güven değerlendirmesi için yeterli veri dağılımı gözlenmemiştir. Bu nedenle, bağımlı değişkenlerin hesaplanabilmesi için güven değerlendirmesi ölçeğinde 1'den 3'e kadar olan yanıtlar "yanlış”, 4'ten 6'ya kadar olan yanıtlar "doğru” olarak kabul edilerek dikotomik hale getirilmiştir.

2 Verilerin analizinde planlı karşılaştırma yapılmasının nedeni, hipotezlere hizmet etmeyen (örneğin, nesneler arası öfke koşulu ile nesne içi üzüntü koşulunun karşılaştırılması gibi) bazı karşılaştırmaların bulunması nedeniyle olası bütün ikili karşılaştırmaları ortaya çıkartmak yerine, araştırmanın amacına uygun olarak hipotezler yönündeki planlı karşılaştırmalar yürütülmüştür. 
Çalışmadan elde edilen verilerden her duygu için isabet oranı (katılımcının "doğru" cevabını verdiği doğru eşleşmelerin sayısı) ve yanlış alarm (YA) oranı (katılımcının “doğru” cevabını verdiği yanlış eşleşmelerin sayısı) hesaplanmıştır.

Alan yazında, tanıma belleği performansının güvenilir ölçümü için sadece doğru yanıtların (isabet oranının) değil, hataların da hesaba katıldığı duyarlılık parametresinin kullanılması önerilmektedir (Macmillan ve Creelman, 2005). Bu çalışmada da isabet oranlarının yanında duyarlılık puanları hesaplanmıştır. İsabet oranının 1 veya YA oranının 0 olduğu durumlarda duyarlılık ve tepki yanlılığ parametreleri hesaplanamadığı için bir düzeltme formülü uygulanmıştır (Bkz. Snodgrass ve Corwin, 1988)³.

Tanıma belleğinde tepki yanlılığı, katılımcıların olası tepkilerden birini daha fazla oranda verme eğilimini ifade etmektedir. En sık kullanılan yanlılık ölçümlerinden ' $c$ ', daha düşük değerlerde katılımcıların daha liberal bir yanlılık gösterdiğine ve "doğru" tepkisi verme eğilimlerinin daha yüksek olduğuna, daha yüksek değerlerde ise muhafazakar (conservative) yanlılığın artarak "yanlış” deme eğiliminin yüksek olduğuna işaret etmektedir (Macmillan ve Creelman, 2005).

\section{BULGULAR}

Araştırmanın hipotezlerinin test edilmesi aşamasına geçilmeden önce değişkenlere ait ortalama, standart sapma ve standart hata değerleri değerlendirilmiştir. Bu değerlere Tablo 1'de yer verilmiştir.

Tablo 1. Değişkenlere Ait Ortalama, Standart Sapma ve Standart Hata Değerleri

\begin{tabular}{|c|c|c|c|c|c|c|c|}
\hline & & \multicolumn{3}{|c|}{ Nesne içi eşleşme } & \multicolumn{3}{|c|}{ Nesneler arası eşleşme } \\
\hline & & Ort. & $S S$ & $\mathrm{SH}$ & Ort. & $S S$ & $\mathrm{SH}$ \\
\hline \multirow{3}{*}{ İsabet Puanları } & Öfke & .77 & .19 & .03 & .82 & .18 & .03 \\
\hline & Üzüntü & .69 & .23 & .04 & .81 & .16 & .03 \\
\hline & Nötr & .79 & .16 & .03 & .85 & .16 & .03 \\
\hline \multirow{3}{*}{ Yanlış Alarm Oranları } & Öfke & .41 & .26 & .04 & .29 & .21 & .04 \\
\hline & Üzüntü & .35 & .25 & .04 & .27 & .20 & .03 \\
\hline & Nötr & .36 & .24 & .04 & .28 & .24 & .04 \\
\hline \multirow{3}{*}{ Duyarlılık Puanları } & Öfke & 1.10 & 1.08 & .18 & 1.64 & .90 & .15 \\
\hline & Üzüntü & 1.03 & 1.11 & .19 & 1.66 & .84 & .14 \\
\hline & Nötr & 1.32 & .99 & .17 & 1.79 & .83 & .14 \\
\hline \multirow{3}{*}{ Yanlılık Puanları } & Öfke & -.29 & .44 & .07 & -.17 & .42 & .07 \\
\hline & Üzüntü & -.06 & .50 & .08 & -.13 & .39 & .07 \\
\hline & Nötr & -.23 & .39 & .07 & -.19 & .49 & .08 \\
\hline
\end{tabular}

Notlar: Ort; ; Ortalama, SS; Standart Sapma, SH; Standart Hata'yı ifade etmektedir.

3 İsabet oranının 1 olduğu durumlar için (İsabet oranı $+0,5) /($ doğru eşleşmeler +1$)$, Yanlış Alarm oranının 0 olduğu durumlar için (YA + 0,5) / (Yanlış eşleşmeler + 1) formülüyle yeni değerler hesaplanmıştır. 


\section{İsabet ve Yanlış Alarm Oranları}

İsabet oranlarının koşula ve duyguya göre farklılaşıp farklılaşmadığına yönelik hipotez sınamak üzere yapılan varyans analizi sonuçlarına Şekil 2'de yer verilmiştir.

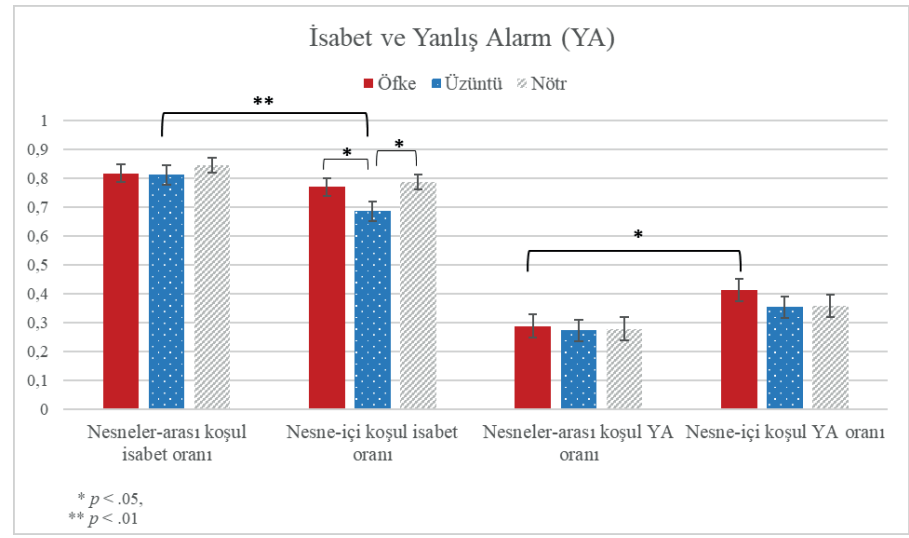

Şekil 2. İsabet ve Yanlış Alarm Oranlarına Yönelik Olarak Yapılan Varyans Analizi Sonuçları

Analiz sonucunda nesneler arası koşuldaki üzgün yüz-ş̧apka eşleşmesinin isabet ora$\mathrm{n} 1($ Ort. $=.81, S S=.16)$ nesne içi koşuldaki üzgün yüz-şapka eşleşmesinin isabet oranına $($ Ort. $=.69, S S=.23)$ göre anlamlı olarak daha yüksek bulunmuştur, $F(1,71)=7.29$, $p<.01, \eta_{\mathrm{p}}{ }^{2}=.09$. Bununla birlikte, nesne içi koşuldaki üzgün yüz-şapka eşleşmesinin isabet oranı (Ort. $=.69, S S=.23)$ nesne içi öfkeli yüz (Ort. $=.77, S S=.19)$ koşulunda göre, $\mathrm{F}(1,35)=4.66, p<.05, \eta_{\mathrm{p}}^{2}=.12$ daha düşüktür. Aynı zamanda, nesne içi koşuldaki üzgün yüz-şapka eşleşmesinin isabet oranı nesne içi nötr yüz eşleşmelerin isabet oranına $($ Ort. $=.79, S S=.16)$ göre daha düşüktür, $F(1,35)=5.87, p<.05, \eta_{\mathrm{p}}{ }^{2}=.14$. Ancak, isabet oranının verisi bazı koşullar için normal dağılım göstermemiştir.

Yanlış alarm oranlarına bakıldığında hipotezler temelinde yapılan planlı karşılaştırma sonuçlarına göre, nesne içi koşuldaki öfkeli yüz-şapka eşleşmesinin YA oranı ( Ort. $=$ $.41, S S=.26)$ nesneler arası koşuldaki öfkeli yüz-şapka eşleşmesinin YA oranına (Ort. $=$ $.29, S S=.21)$ göre anlamlı olarak daha yüksektir, $F(1,71)=5.26, p<.05, \eta_{\mathrm{p}}{ }^{2}=.07$.

\section{Duyarlılık (d')}

Alanda duyarlılık ölçümü için isabet ve YA oranlarının $z$ değerleri arasındaki fark hesaplanmaktadır (Macmillan ve Creelman (2005). Bu çalışmada da benzer formül ile duyarlılık puanları hesaplanmıştır. ${ }^{4}$

$4 \quad d^{\prime}=z_{\text {isabet }}-z_{\mathrm{YA}}$ 
Her bir koşulun kendi içindeki duygu koşulları arasında farklılaşma olup olmadığını test etmek üzere yapılan duyarlılık analizi yapılmıştır. Buna göre, yüksek uyarılmışlık (öfke), düşük uyarılmışlık (üzüntü) ve nötr duygu kategorileri arasında hem nesne içi koşuldaki duygu eşleşmeleri $(p>0.5)$ hem de nesneler arası koşuldaki duygu eşleşmeleri $(p>.05)$ açısından bir farklılık olmadığg görülmüştür (Bkz. Şekil 3.).

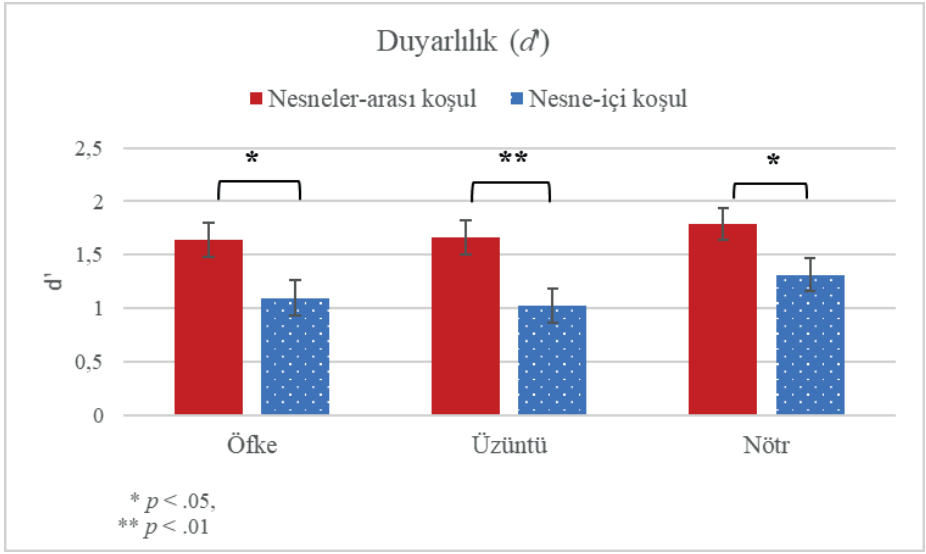

Şekil 3. Duyarlılık Puanlarına Yönelik Yapılan Varyans Analizi Sonuçları

Bu çalışmanın ikinci hipotezi açısından yapılan planlı karşılaştırmalarda her bir duygu kategorisi açısından, duygu kategorilerinin nesne içi ve nesneler arası farklılaşmasına bakıldığında; nesneler arası öfke eşleşmeleri (Ort. $=1.64, S S=0.90)$ nesne içi öfke $($ Ort. $=1.10, S S=1.08)$ koşulundaki eşleşmelerden daha iyi ayırt edilmiştir, $F(1,71)=$ $5.49, p<.05, \eta_{\mathrm{p}}{ }^{2}=.07$. Benzer şekilde nesneler arası üzüntü eşleşmeleri (Ort. $=1.66, S S$ $=0.84)$, nesne içi üzüntü eşleşmelerinden $($ Ort. $=1.03, S S=1.11)$ daha iyi ayırt edilmiştir, $\mathrm{F}(1,71)=7.69, \mathrm{p}<.01, \eta \mathrm{p} 2=.10$. Son olarak, nesneler aras1 nötr eşleşmeleri (Ort. $=$ $1.79, S S=0.83)$ nesne içi nötr eşleşmelerden $($ Ort. $=1.32, S S=0.99)$ daha iyi ayırt edilebilmiştir, $F(1,71)=4.93, p<.05, \eta_{\mathrm{p}}^{2}=.07$. Ancak yüksek uyarılmışlık ifade eden duygu kategorisi (öfke) ile düşük uyarılmışlık ifade eden duygu koşulu (üzüntü) arasında hem nesne içi koşulda $(p>.05)$, hem de nesneler arası koşulda $(p>.05)$ anlamlı bir farklılık ortaya çıkmamıștır.

\section{Tepki Yanlılığı (c)}

Katılımcıların herhangi bir koşula ya da duygu kategorisine yönelik tepki yanlılığını test etmek üzere hesaplanan yanlılık puanına $(c)^{5}$ yönelik olarak yapılan planlı karşılaştır$5 \quad c=-.5^{*}\left(z_{\text {isabet }}+z_{\mathrm{YA}}\right)$ 
ma sonuçlarına göre anlamlı olan tek farklılaşma, nesne içi koşuldaki üzgün yüz-şapka eşleşmelerine olan tepki yanlılığının (Ort. $=-.06, S S=.50)$ aynı koşuldaki öfkeli yüz-şapka eşleşmelerine olan tepki yanlılığına (Ort. $=-.29, S S=.44)$ göre daha yüksek olmasıdır, $F(1,35)=8.05, p<.05$ kısmi $\eta^{2}=.187$. Analiz sonuçlarına Şekil 4'de yer verilmiştir.

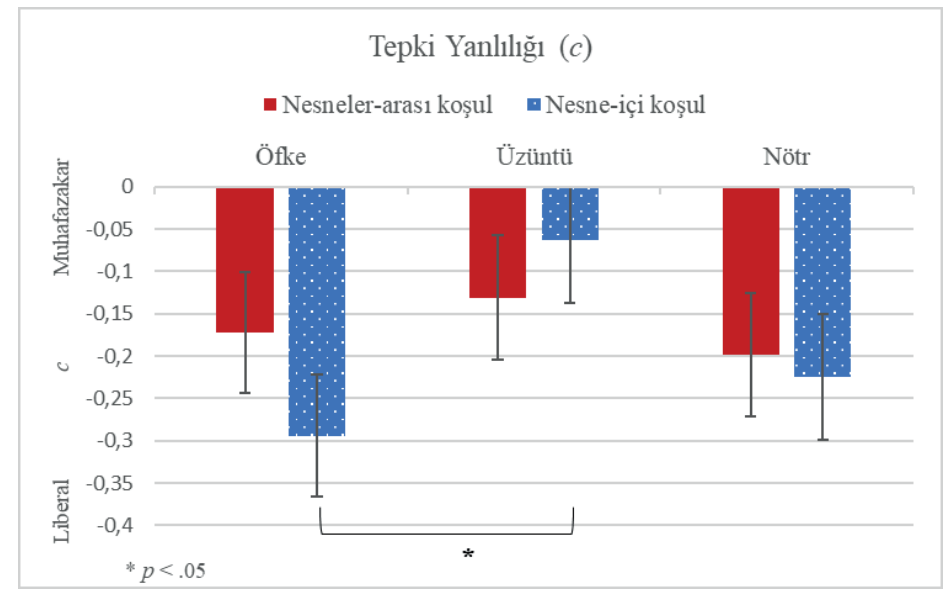

Şekil 4. Tepki Yanlılığı Puanlarına Yönelik Yapılan Varyans Analizi Sonuçları

\section{TARTIŞMA}

Bu çalışmada hem negatif hem de uyarılmışlık düzeyi yüksek ve düşük duyguların eşleşme türüne (nesne içi ve nesneler arası bağlantılara) göre belleğin güncellenmesi üzerindeki etkisi ileriye ket vurma yöntemiyle araştırılmıştır. Bunun için öfkeli, üzgün ve nötr yüzler çeşitli şapkalar ile eşleştirilmiştir. Bir koşulda şapka yüzün içsel özelliği olarak sunulmuşken diğer koşulda dışsal özellik olarak sunulmuştur. İleriye ket vurmayı test etmek için klasik bir AB/AC paradigmasıyla katılımcılar önce bir dizi yüz-şapka eşleşmelerini öğrenmişlerdir, ikinci aşamada ise daha önce gördükleri yüzler ile yeni şapka eşleşmelerini öğrenmişlerdir. Test aşamasında katılımcılara AC çiftleri doğru veya yanlış eşleştirilmiş halde sunulmuştur ve katılımcılardan sunulan eşleşmenin doğru mu yanlış mı olduğuna karar vermeleri beklenmiştir.

Deneyde kullanılan öfke, üzüntü ve nötr duygu eşleşmelerinin karşılaştırılmasıyla elde edilen anlamlı etkiler, döngüsel modelde (Posner, Russell ve Peterson, 2005; Russell, 1980) öfke duygusunun yüksek uyarılmışlık, üzüntü duygusunun ise düşük uyarılmışlık boyutunda olmasına dayanarak, duygunun uyarılmışlık boyutundan kaynaklandığ1 sonucunu ortaya çıkarttığına işaret etmektedir. Ancak her ne kadar duygular 
arasındaki uyarılmışlık farkı bu türden kuramsal bir temele dayansa da, çalışmada kullanılan duygusal uyaranların uyarılmışlık düzeyinden emin olmak için uyaranların değerlendirilmesi gerekmiştir. Bu amaçla deney sonrası yapılan bir ek çalışmada, deneyde kullanılan uyaranlar bir grup katılımcı tarafından değerlendirilmiştir. Bu ek çalışmada, asıl deneyde kullandığımız yüz ifadeleri uyaranlarının (72 uyaran) uyarılmışlık düzeylerinin değerlendirmesi 1 (düşük uyarılmışlık) ile 7 (yüksek uyarılmışlık) arasında The Self-Assesment Manikin - SAM (Lang, 1980) kullanılarak online form aracılı̆̆ıyla alınmıştır. Ege Üniversitesi Edebiyat Fakültesi Psikoloji Bölümü’nde öğrenim gören 26 katılımcıdan (21 kadın, 5 erkek) elde edilen veriler tekrarlı ölçümler için varyans analizi yöntemi ile test edilmiştir. Çalışma sonunda öfkeli yüz ifadelerinin üzgün yüz ifadelerinden $(p<.01)$ ve nötr yüz ifadelerinden $(p<.001)$ daha yüksek uyarılmışlık ifade ettiği görülmüştür. Aynı zamanda üzgün yüz ifadelerinin nötr yüz ifadelerinden, uyarılmışlık düzeyi açısından daha yüksek puanlandığg görülmüştür $(p<.001)$. Bu sonuçlar, öfke duygusunun üzüntü duygusundan daha yüksek uyarılmışlık düzeyinde olduğunu göstermiştir ve asıl deneyde ortaya çıkan etkilerin duygusal uyarılmışlıktan kaynaklandığına işaret etmektedir.

Asıl çalışmadan elde edilen sonuçlara bakıldığında nesne içi koşuldaki öfkeli yüz-şapka eşleşmelerinin YA oranı, nesneler arası koşulundaki öfkeli yüz-şapka eşleşmelerinin YA oranına göre daha yüksektir. Başka bir ifadeyle katılımcılar, öfkeli yüz-şapka eşleşmelerinde nesne içi koşulda, nesneler arası koşula kıyasla daha fazla hata yapmışlardır. Bu bulgu, yüksek uyarılmışlık ifade eden duygunun nesne içi eşleşmelerde belleğin güncellenmesini zorlaştırdığı açıklamasıyla ve Nesne Temelli İlişkilendirme Kuramı ile (Mather, 2007) tutarlıdır.

Çalışmanın isabet verisi incelendiğinde verilerin normal dağılım göstermediği görülmüştür. Bunun yanında isabet verisi ile duyarlılık verisinden elde edilen bulgular arasında bir tutarsızlık görülmüştür. Alan yazında tanıma belleğinin güvenilir ölçümü için doğru yanıtlar ve hataların birlikte ele alındı̆̆ı duyarlılık (d') parametresinin ele alınmas1 gerektiği önerilmektedir (Macmillan ve Creelman, 2005). Buna dayanarak bu çalışmada da, tanıma belleğinin performansının doğru ölçümü için isabet verisi yerine duyarlılık puanları temel alınmıştır. Tanıma belleği duyarlılığı sonuçlarına göre nesneler arası eşleşme koşulundaki katılımcılar, nesne içi eşleşme koşulundaki katılımcılara göre, her bir duygu kategorisi açısından doğru eşleşmeleri, yanlış eşleşmelerden daha iyi ayırt edebilmişlerdir ve üç duygu kategorisinde de nesneler arası ilişkideki eşleşme- 
ler nesne içi eşleşmelere göre daha iyi tanınmıştır. Bu bulgular, bu çalışmanın hipotezleriyle tutarlı olarak göstermiştir ki, bir uyaranın içsel özelliğinin hatırlanması gerektiğinde ileriye ket vurma gerçekleşmektedir. Bu içsel özellik belleğe kodlandıktan sonra o uyarana ilişkin yeni öğrenme gerçekleşmesi zorlaşmaktadır. Duyarlılık bulgularına göre her bir koşulun kendi içindeki duygu kategorileri arasında anlamlı farklılık bulunamamıştır ve böylece araştırmanın negatif yüksek uyarılmışlığın düşük uyarılmışlığa göre ayırt etme performansını düşüreceği yönündeki hipotezi desteklenmemiştir. Bunun bir nedeni, uyarılmışlı etkisinin sonraki uyaran çiftine geçmesini engellemek amacıyla kullanılan daire görevinin bu konuda yetersiz kalması olabilir. Gelecekteki araştırmalarda tüm duyguları içeren karışık eşleşme blokları sunmak yerine, her duygunun kendi içinde ayrı bir blokta sunulduğu koşullar yaratarak bunun önüne geçilebilir. İkinci bir olası sebep ise, deneyde anlık tanıma belleği ölçümü alınmış olmasıdır. Alan yazında, duygunun bellek üzerindeki etkisinin duygusal uyaranın bellekte amigdala-hipokampüs arası etkileşimin sonucu olarak ayrıcalıklı sağlamlaştırılmasından kaynaklandığı düşünülmektedir. Bu sağlamlaştırma sürecinin belli bir zaman alması nedeniyle de duygunun bellek üzerindeki etkisinin ancak öğrenmenin üzerinden belli bir süre geçtikten sonra ortaya çıtı̆̆ını gösteren araştırmalar mevcuttur (Cahill, Gorski ve Le, 2003; Pierce ve Kensinger, 2011; Sharot ve Yonelinas, 2008). Bu nedenle gelecek çalışmalarda tanıma testinin öğrenme aşamasından hemen sonra yapılması yerine, gecikmeli olarak (örn. 24 saat sonra) yapılmasının duygular arasında bir farklılaşmayı ortaya çıkartabileceği düşünülmektedir.

Tepki yanlılı̆̆ sonuçlarına bakıldığında, nesne içi koşuldaki üzgün yüz-şapka eşleşmelerinde katılımcıların konservatif tepki yanlılığı gösterdiği görülmüştür. Başka bir ifadeyle, katılımcılar nesne içi koşuldaki üzgün yüz-şapka eşleşmelerine daha çok 'yanlış eşleşme' yanıtını vermişlerdir. Buna göre negatif düşük uyarılmışlık düzeyi, nesne içi eşleşmeler koşulunda katılımcıların kararlarına olan güvenini etkilemiştir. Bu bulgu, alan yazında yüksek uyarılmışlığın katılımcılarda liberal yönde tepki yanlılı̆̆ gösterdiğine yönelik bulgular ile tutarlı görünmektedir (Dougal ve Rotello, 2007; Kapucu, Rotello, Ready ve Seidl, 2008).

Bu çalışmadaki sınırlılıklardan birisi standardizasyonu olmayan şapka uyaranlarının kullanılmış olmasıdır. Şapka fotoğrafları belirli ölçütlere göre seçilmiş olsalar da şapkaların bilinmeyen etkiler yaratmış olma ihtimali vardır. Bu olası etkiyi kontrol edebilmek adına her katılımcı için dört farklı eşleştirme listesinden bir tanesi tesadüfi olarak seçil- 
miş ve eşleşmelerin her bir katılımcıya sunum sırası seçkisiz olacak şekilde ayarlanmıştır. Ancak sonraki çalışmalarda kullanılacak olan nesne uyaranları için bir standardizasyon çalışmasının yapılması önerilmektedir. Benzer şekilde bu çalışmadaki bir diğer sınırlılık, kişilerin yüz ve şapka nesneleri arasında negatif duygusal uyarılmışlık dışında anlamsal bir bağ kurmuş olmaları olasılı̆̆ıdır. Kişiler nesne içi ve nesneler arası koşullarda duygusal etkilerden ziyade anlamsal ilişkilendirme stratejileriyle nesneleri ilişkilendirmiş olabilir. Sonraki çalışmaların bu türden alternatif açıklamaları test etmesi yararlı olacaktır.

Uyaranlara ilişkin tartışılabilir başka bir konu da nesne içi koşuldaki şapkanın nesnenin içsel bir özelliği olarak kabul edilip edilemeyeceğidir. Alandaki çalışmalarda nesnenin rengi ya da bir alandaki konumu gibi özellikleri nesnenin içsel özelliği olarak değerlendirilmiştir (D’Argembeau ve Van der Linden, 2004; Doerksen ve Shimamura, 2001; Mather ve Nesmith, 2008). Ancak mevcut çalışmada içsel veya dişsal bir özellikten ziyade yüz ve şapka arasındaki mesafe farkından söz etmek mümkündür. Örneğin; MacKenzie, Powell ve Donaldson (2015) renk bağlamının içsel ve dışsal bağlantı farkını ele aldıkları çalışmada farklı bir yol izleyerek, sunulan fotoğrafın çerçeve rengini değiştirerek dışsal bağlantı, fotoğrafın üzerine renkli bir filtre uygulayarak ise içsel bağlantı koşullarını oluşturmuştur. Öte yandan, bu çalışmada Özellik Bütünleştirme Kuramı'nın (Kahneman, Treisman ve Gibbs, 1992) önerdiği biçimde, yüz uyaranları ile benzer konumu paylaşmalarından dolayı şapka uyaranları içsel özellik olarak değerlendirilmiştir. Ancak Scholl (2001), aynı konumda olsalar bile iki farklıuyaranın, nesne temelli algılanacağını öne sürer. Dolayısıyla bu çalışmanın bir sınırlılığı olarak Nesne Temelli İşleme Kuramı'nın yaklaşımı doğrudan test edilmemiştir. Bu tartışmayla paralel biçimde, bu çalışmada ortaya çıkan sonucun negatif duygusal uyarılmışlık etkisinden ziyade, iki koşul arasındaki dikkatin yönlenmesine bağlı farklılıktan kaynaklandığı da düşünülebilir. Her ne kadar bu çalışma öncesi yapılan pilot çalışmada, koşullar arasında bir öğrenme farklılığı ortaya çıkmasa da, sonraki çalışmaların kişilerin farklı nesneler arası süreçlerdeki dikkatlerini yönlendirme stratejilerini göz önünde bulundurması önemli görünmektedir. Gelecek çalışmalarda, içsel ve dışsal bağlantıya ilişkin bu türden alternatif yaklaşımların ele alınması ve bu çalışmanın tekrarlanmasının faydalı olacağı düşünülmektedir.

Bu çalışmada alanda sıklıkla kullanılan ileriye ket vurma paradigmalarından $\mathrm{AB} / \mathrm{AC}$ paradigması tanıma testiyle kullanılmış olsa da, tipik olarak ileriye ket vurma çalışmalarında test aşamasında geri çağırma (recall) performansı ölçülmektedir. Geri çağırma ça- 
lışmalarında test aşamasında katılımcıların hem ilk eşleşme (AB) hem de ikinci eşleşme (AC) performansları karşılaştırılarak ileriye ket vurma etkisine yönelik açıklamalar yapılabilmektedir. Ancak bu çalışmada tanıma testinde, ikinci eşleşmenin geri çağırma görevinde olduğu gibi bir ipucuyla alınması bazı teknik ve kuramsal sorunlara yol açabileceğinden (katılımcıların aynı yüz ifadelerini tekrar görmelerine bağlı etkiler, fotoğrafların kelime listelerinde olduğu gibi ipucuyla sunulmasına ilişkin sorunlar vb.), birinci ve ikinci eşleşmeler arasındaki tanıma performansı doğrudan karşılaştırılamamıştır. Bu soruna yönelik olarak, yeterli öğrenme için gerekli deneme sayısını belirlemek üzere deney öncesi yaptığımız pilot çalışma verileri 2 (koşul) x 3 (duygusal uyarılmışlık) varyans analizi ile test edilmiştir. Sonuçlarda koşul (nesneler arası ve nesne içi) temel etkisi, duygu temel etkisi (öfke, üzüntü, nötr) ve koşul ile duygu etkileşiminin isabet oranı, yanlış alarm, duyarlılık ve yanlılık puanları açısından istatistiksel olarak anlamlı olmadığı görülmüştür. Bu sonuçlar, yüz ve şapka eşleşmelerinin öğrenilmesinin koşula ve duyguya bağlı olarak farklılaşmadığını göstermiş, böylece asıl deneyde ortaya çıkan farkın öğrenme aşamasındaki bir farklılıktansa, iki testin öğrenilmesi arasındaki süreçten yani bu çalışmanın konusu açısından ileriye ket vurma etkisinden kaynaklandığına ilişkin bilgi sağladığı düşünülmektedir. Ancak bu açıklama ileriye ket vurmaya ilişkin dolaylı bir bilgi vermesi açısından bu çalışmanın bir sınırlılı̆̆ı olarak değerlendirilebilir. Gelecek çalışmalarda ortaya çıkan etkinin ileriye ket vurmadan kaynaklanıp kaynaklanmadığı sorusunun farklı ve yeni yöntemler ile test edilmesi gerekmektedir. Deney aşamasına yeni koşullar eklenerek ya da ileriye ket vurmaya yönelik farklı paradigmalar kullanılarak bu çalışmadaki soruların yeniden ele alınması önemlidir.

Son olarak, pek çok çalışmada olduğu gibi bu çalışmada da uyarılmışlık düzeyini değişimlemek için yüz ifadesi fotoğrafları kullanılmıştır. Kullanılan uyaranlar her ne kadar standart veri tabanlarından seçilmiş olsa da farklı uyaran türleriyle (video, ses, vb.) ve kişinin hissettiği duygunun değişimlenmesiyle (duygu sevki yöntemleri) yapılacak olan yeni çalışmalar uyarılmışlığın bellek üstündeki ketleyici etkisini aydınlatmaya katkı sağlayacaktır.

Sonuç olarak, nesne içi eşleşmelerin nesneler arası eşleşmelere kıyasla, ileriye ket vurmadan daha fazla etkilendiği görülmüştür. Negatif yüksek uyarılmışlık durumunda nesne içi eşleşmelerde daha fazla yanlış alarm ortaya çıkması, nesne içi bilginin bir kez kodlandıktan sonra yeni öğrenmelere karşı daha dirençli olduğuna işaret etmektedir. Bununla paralel olarak katılımcılar nesne içi eşleşmeleri ayırt etmede, nesneler arası eşleşmelere 
göre daha başarısız olmuştur. Böylece, içsel bir özelliğin kodlanmasının yeni öğrenmelerin hatırlanmasını zorlaştırdığı görülmüştür. Bu sonuçlar çalışmanın ilk hipotezi olan nesne içi öğrenmelerin ileriye ket vurmaya yol açacağı beklentisiyle tutarlıdır. Ancak çalışmanın ikinci hipotezi olarak negatif duygusal uyarılmışlığın rolüne ilişkin hipotez desteklenmemiştir. İleriki çalışmalarda duygusal uyarılmışlık ve nesneler arası ilişkilerin farklı deneysel paradigmalarla ve bellek yaklaşımlarıyla ele alınması yararlı olacaktır. Bunun yanında her ne kadar duygu ve bellek ilişkisi son yıllarda Türkiye'deki araştırmaların konusu olsa da (örn., Kapucu ve ark., 2018; Kaynak ve Gökçay, 2017; Sayar, 2013), yeni çalışmalarla kültürler arası etkilerin test edilmesi önemli görünmektedir.

Finansal Destek: Yazarlar bu çalışma için finansal destek almamışlardır.

\section{Kaynakça}

Bisby, J. A. ve Burgess, N. (2014). Negative affect impairs associative memory but not item memory. Learning and Memory, 21, 760-766. doi: 10.1101/lm.032409.113

Bradley, M. M., Greenwald, M. K., Petry, M. C. ve Lang, P. J. (1992). Remembering pictures: Pleasure and arousal in memory. Journal of Experimental Psychology: Learning, Memory, and Cognition, 18, 379-390. doi: 10.1037/0278-7393.18.2.379

Cahill, L., Gorski, L. ve Le, K. (2003). Enhanced human memory consolidation with post-learning stress: Interaction with the degree of arousal at encoding. Learning \& Memory, 10, 270-274. doi: $10.1101 / 1 \mathrm{~m} .62403$

Cahill, L., Haier, R. J., Fallon, J., Alkire, M. T., Tang, C., Keator, D. ve ... McGaugh, J. L. (1996). Amygdala activity at encoding correlated with long-term, free recall of emotional information. Proceedings of the National Academy of Sciences of the United States of America, 93, 8016-8021. doi: 10.1073/pnas.93.15.8016

Cahill, L. ve McGaugh, J. L. (1995). A novel demonstration of enhanced memory associated with emotional arousal. Consciousness and Cognition, 4, 410-421. doi: 10.1006/ccog.1995.1048

Contini, L. ve Whissell, C. (1992). Memory disadvantages for CVC associates of emotional words. Perceptual and Motor Skills, 75(2), 427-431. doi:10.2466/pms.1992.75.2.427

D'Argembeau, A. ve Van der Linden, M. (2004). Influence of affective meaning on memory for contextual information. Emotion, 4(2), 173-188. doi: 10.1037/1528-3542.4.2.173

Doerksen, S. ve Shimamura, A. P. (2001). Source memory enhancement for emotional words. Emotion, 1(1), 5-11. doi:10.1037/1528-3542.1.1.5

Dougal, S. ve Rotello, C. M. (2007). "Remembering" emotional words is based on response bias, not recollection. Psychonomic Bulletin \& Review, 14(3), 423-429. doi: 10.3758/BF03194083

Easterbrook, J. A. (1959). The effect of emotion on cue utilization and the organization of behavior. Psychological Review, 66(3), 183-201. doi: 10.1037/h0047707

Ebner, N. C., Riediger, M. ve Lindenberger, U. (2010). FACES-A database of facial expressions in young, middle-aged, and older women and men: Development and validation. Behavior Research Methods, 42(1), 351-362. doi: 10.3758/BRM.42.1.351

Guillet, R. ve Arndt, J. (2009). Taboo words: The effect of emotion on memory for peripheral information. Memory \& Cognition, 37(6), 866-879. doi: 10.3758/MC.37.6.866 
Hamann, S. B., Ely, T. D., Grafton, S. T. ve Kilts, C. D. (1999). Amygdala activity related to enhanced memory for pleasant and aversive stimuli. Nature Neuroscience, 2(3), 289. doi: 10.1038/6404.

Johnson, M. K., ve Raye, C. L. (2000). Cognitive and brain mechanisms of false memories and beliefs. D.L. Schacter ve E. Scarry (Eds.), Memory, brain, and belief içinde (ss. 35-86). Cambridge, MA: Harvard University Press.

Kahneman, D., Treisman, A. ve Gibbs, B. J. (1992). The reviewing of object files: Object-specific integration of information. Cognitive Psychology, 24(2), 175-219. doi: 10.1016/00100285(92)90007-O

Kapucu, A., Rotello, C. M., Ready, R. E. ve Seidl, K. N. (2008). Response bias in "remembering" emotional stimuli: A new perspective on age differences. Journal of Experimental Psychology: Learning, Memory, and Cognition, 34(3), 703-711. doi:10.1037/0278-7393.34.3.703

Kapucu, A., Arıkan İyilikçi, E., Eroğlu, S. ve Amado, S. (2018). Kodlama öncesi veya geri getirme öncesi sevk edilen korku ve kızgınlık duygularının tanıma belleği performansına etkileri. Türk Psikoloji Dergisi, 33(82), 85-99. doi: 10.31828/tpd.13004433.2018.82.02.06

Kaynak, H. ve Gökçay, D. (2017). Response bias shift for positive words in older adults in a surprise recognition memory task: An incidental encoding study. Turkish Journal of Geriatrics, 20, 331-343.

Kensinger, E. A., Brierley, B., Medford, N., Growdon, J. H. ve Corkin, S. (2002). Effects of normal aging and Alzheimer's disease on emotional memory. Emotion, 2(2), 118-134. doi: 10.1037/15283542.2.2.118

Kensinger, E. A. ve Corkin, S. (2003). Memory enhancement for emotional words: Are emotional words more vividly remembered than neutral words? Memory \& Cognition, 31(8), 1169-1180. doi: 10.3758/BF03195800

Kensinger, E. A. ve Schacter, D. L. (2008). Memory and emotion. M. Lewis, J. M. Haviland-Jones ve L. Barrett (Ed.), Handbook of emotions içinde (3. bask1) (ss. 601-617). New York, NY: Guilford Press.

Knight, M., Seymour, T. L., Gaunt, J. T., Baker, C., Nesmith, K. ve Mather, M. (2007). Aging and goaldirected emotional attention: Distraction reverses emotional biases. Emotion, 7(4), 705-714. doi: 10.1037/1528-3542.7.4.705

LaBar, K. S., Mesulam, M. M., Gitelman, D. R. ve Weintraub, S. (2000). Emotional curiosity: Modulation of visuospatial attention by arousal is preserved in aging and early-stage Alzheimer's disease. Neuropsychologia, 38(13), 1734-1740. doi: 10.1016/S0028-3932(00)00077-4

Lang, P. J. (1980). Behavioral treatment and bio-behavioral assessment. J. B. Sidowski, J. H. Johnson ve T. A. Williams (Ed.), Technology in mental health care delivery systems içinde (ss. 119-167). Norwood, NY: Ablex.

Lee, K.Y., Lee, T.-H., Yoon, S.J., Cho, Y. S., Choi, J. S. ve Kim, H. T. (2010). Neural correlates of top-down processing in emotion perception: An ERP study of emotional faces in white noise versus noise-alone stimuli. Brain Research, 1337, 56-63. doi: 10.1016/j.brainres.2010.03.094

MacKay, D. G., Shafto, M., Taylor, J. K., Marian, D. E., Abrams, L. ve Dyer, J. R. (2004). Relations between emotion, memory, and attention: Evidence from taboo Stroop, lexical decision, and immediate memory tasks. Memory \& Cognition, 32(3), 474-488. doi: 10.3758/BF03195840

MacKenzie, G., Powell, T. F. ve Donaldson, D. I. (2015). Positive emotion can protect against source memory impairment. Cognition and Emotion, 29(2), 236-250. doi: 10.1080/02699931.2014.911145

Macmillan, N. A. ve Creelman, C. D. (2005). Detection theory: A user's guide (2. bask1). Mahwah, NJ, US: Lawrence Erlbaum Associates Publishers.

Mather, M. (2007). Emotional arousal and memory binding: An object-based framework. Perspectives on Psychological Science, 2(1), 33-52. doi: 10.1111/j.1745-6916.2007.00028.x 
Mather, M. ve Knight, M. (2008). The emotional harbinger effect: Poor context memory for cues that previously predicted something arousing. Emotion, 8(6), 850-860. doi:10.1037/a0014087

Mather, M. ve Nesmith, K. (2008). Arousal-enhanced location memory for pictures. Journal of Memory and Language, 58(2), 449-464. doi: 10.1016/j.jml.2007.01.004

Mather, M. ve Sutherland, M. (2009). Disentangling the effects of arousal and valence on memory for intrinsic details. Emotion Review, 1(2), 118-119. doi: 10.1177/1754073908100435

Mather, M. ve Sutherland, M. R. (2011). Arousal-Biased Competition in Perception and Memory. Perspectives on Psychological Science, 6(2), 114-133.

doi: 10.1177/1745691611400234

Mitchell, K. J., Mather, M., Johnson, M. K., Raye, C. L. ve Greene, E. J. (2006). A functional magnetic resonance imaging investigation of short-term source and item memory for negative pictures. Neuroreport, 17(14), 1543-1547. doi:10.1097/01.wnr.0000234743.50442.e5

Nagae, S. ve Moscovitch, M. (2002). Cerebral hemispheric differences in memory of emotional and nonemotional words in normal individuals. Neuropsychologia, 40(9), 1601-1607. doi: 10.1016/ S0028-3932(02)00018-0

Novak, D. L. ve Mather, M. (2009). The tenacious nature of memory binding for arousing negative items. Memory \& Cognition, 37(7), 945-952. doi: 10.3758/MC.37.7.945

Nummenmaa, L., Hyönä, J. ve Calvo, M. G. (2006). Eye movement assessment of selective attentional capture by emotional pictures. Emotion, 6(2), 257-268. doi:10.1037/1528-3542.6.2.257

Pierce, B. H. ve Kensinger, E. A. (2011). Effects of emotion on associative recognition: Valence and retention interval matter. Emotion, 11(1), 139-144. doi: 10.1037/a0021287

Posner, J., Russell, J. A. ve Peterson, B. S. (2005). The circumplex model of affect: An integrative approach to affective neuroscience, cognitive development, and psychopathology. Development and Psychopathology, 17(3), 715-734. doi: 10.10170S0954579405050340

Rösler, A., Ulrich, C., Billino, J., Sterzer, P., Weidauer, S., Bernhardt, T., ... ve Kleinschmidt, A. (2005). Effects of arousing emotional scenes on the distribution of visuospatial attention: Changes with aging and early subcortical vascular dementia. Journal of the Neurological Sciences, 229, 109-116. doi: $10.1016 /$ j.jns.2004.11.007

Russell, J. A. (1980). A circumplex model of affect. Journal of Personality and Social Psychology, 39(6), 1161-1178. doi: 10.1037/h0077714

Russell, J. A. ve Barrett, L. F. (1999). Core affect, prototypical emotional episodes, and other things called emotion: Dissecting the elephant. Journal of Personality and Social Psychology, 76(5), 805819. doi: $10.1037 / 0022-3514.76 .5 .805$

Sakaki, M., Ycaza-Herrera, A. E. ve Mather, M. (2014). Association learning for emotional harbinger cues: When do previous emotional associations impair and when do they facilitate subsequent learning of new associations? Emotion, 14(1), 115-129. doi:10.1037/a0034320

Sayar, F. (2013). Gençlerin ve yaşlıların otobiyografik bellek özellikleri açısından karşılaştırılması: Betimsel bir çalışma. Psikoloji Çalı̧̧maları, 33(1), 1-16.

Scherer, K. R. (2005). What are emotions? And how can they be measured? Social Science Information, 44(4), 695- 729. doi: 10.1177/0539018405058216

Scholl, B. J. (2001). Objects and attention: The state of the art. Cognition, 80(1-2), 1-46. doi: 10.1016/ S0010-0277(00)00152-9

Sharot, T. ve Yonelinas, A. P. (2008). Differential time-dependent effects of emotion on recollective experience and memory for contextual information. Cognition, 106(1), 538-547. doi: 10.1016/j. cognition.2007.03.002 
Snodgrass, J. G. ve Corwin, J. (1988). Pragmatics of measuring recognition memory: Applications to dementia and amnesia. Journal of Experimental Psychology: General, 117(1), 34-50. doi: 10.1037/0096-3445.117.1.34

Tooby, J. ve Cosmides, L. (2008). The evolutionary psychology of the emotions and their relationship to internal regulatory variables. M. Lewis, J. M. Haviland-Jones ve L. Barrett (Ed.), Handbook of emotions içinde (3. baskı) (ss. 114-137). New York, NY: Guilford Press.

Tyng, C. M., Amin, H. U., Saad, M. N. ve Malik, A. S. (2017). The influences of emotion on learning and memory. Frontiers in Psychology, 8. doi: 10.3389/fpsyg.2017.01454

White, C. N., Kapucu, A., Bruno, D., Rotello, C. M. ve Ratcliff, R. (2014). Memory bias for negative emotional words in recognition memory is driven by effects of category membership. Cognition \& Emotion, 28(5), 867-880. doi:10.1080/02699931.2013.858028 
Ek 1. Uyaran eşleşmelerinin örnek gösterimi

Nesne içi koşuldaki eşleşme örneği

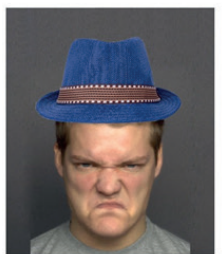

Nesne arası koşuldaki eşleşme örneği

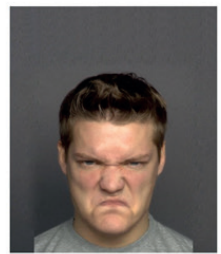

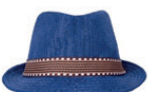

